\title{
Propionibacterium acnes Infection in Disc Material and Different Antibiotic Susceptibility in Patients With Lumbar Disc Herniation
}

\author{
FIROOZ SALEHPOUR, MD, JAVAD AGHAZADEH, MD, FARHAD MIRZAEI, MD, EHSAN ZIAEII, MD, \\ SEYED AHMAD NASERI ALAVI, MD \\ Department of Neurosurgery, Faculty of Medicine, Tabriz University of Medical Sciences, Tabriz, Iran
}

\begin{abstract}
Background: Low back pain is an important, worldwide clinical problem from which human populations are suffering. It has been suggested that Propionibacterium acnes is associated with low back pain. The objective of this clinical study is to evaluate the $P$. acnes infection in the disc material and antibiotic susceptibility in patients with disc herniation.

Methods: A total of 120 patients with disc herniation surgery were enrolled in the study. The samples were excited during discectomy and then cultured in both anaerobic and aerobic incubations. Minimum inhibitory concentration (MIC) was performed for determination of antibiotic susceptibility.

Results: Of 120 samples, $60(50 \%)$ samples were positive for microorganisms. Disc herniation was at the level of L4-L5 in 63 cases and L5-S1 in 57 cases.

Conclusions: According to the results and presence of $P$. acnes in more than $35 \%$ of the cultured samples, the presence of $P$. acnes in lumbar disc herniation is a suspected element leading to this condition. After analysis of the antibiotics, the lowest MIC value was identified for amoxicillin, ciprofloxacin, erythromycin, rifampicin, tetracycline, vancomycin; the moderate MIC value was for fusidic acid; and the highest MIC value was for gentamicin and trimethoprim.
\end{abstract}

Lumbar Spine

Keywords: Propionibacterium acnes, lumbar disc herniation, low back pain, antibiotics

\section{INTRODUCTION}

Low back pain (LBP) is the most common social, economic, clinical, and public health problem affecting the human population worldwide. ${ }^{1}$ About $70 \%$ of adults suffer from LBP with various degrees of severity at some time during their lives. ${ }^{2}$ The cause of most LBPs has not been recognized yet. However, the source of LBP is associated with degenerative joints and disc disease in $5 \%$ to $15 \%$ of patients. ${ }^{3}$ In addition, a major cause of discogenic LBP is degenerative changes in the human intervertebral discs especially in the lumbar spine, which occurs during aging. ${ }^{4}$ Discogenic pain in the lumbar spine is related to 3 main factors: mechanical injuries, internal disc disruption, and disc inflammation. ${ }^{5}$ Over the last decade, evidence has emerged that Propionibacterium acnes is associated with a number of clinical conditions such as discogenic LBP and sciatica, ${ }^{6}$ discitis, ${ }^{7}$ and infections related to medical devices. ${ }^{8} P$. acnes is a gram-positive, rod- shaped bacillus that is a human skin commensal and oral microbiota. ${ }^{9}$ It is slow-growing and prefers anaerobic growth conditions and has been documented as a pathogenic factor in the inflammatory skin condition acne vulgaris. ${ }^{10,11}$ Recently, this microorganism has been recognized as a cause of prostatitis leading to prostate cancer, ${ }^{12}$ sarcoidosis, ${ }^{13,14}$ synovitis, pustulosis, hyperostosis, and osteitis syndrome, and chronic recurrent multifocal osteomyelitis $^{15}$ as well as sciatica. ${ }^{6}$ Also, it has been suggested that $P$. acnes can be observed in various kinds of implant-associated infections, including neurosurgical shunts, ${ }^{16,17}$ ocular implants, ${ }^{18}$ breast implants, ${ }^{19,20}$ cardiovascular devices, ${ }^{21}$ spinal hardware, ${ }^{22-24}$ internal fracture fixation devices, ${ }^{25,26}$ and prosthetic joints. ${ }^{27,28}$ Previously, it was reported that bacteria cultures of disc herniations were positive for about $46 \%$ of cases, of which $86 \%$ were related to $P$. acnes. $^{29}$ Moreover, using antibiotics could improve LBP in patients with herniated 
lumbar discs. ${ }^{30}$ However, there is no agreement on the origin of this pathogen in the disc tissue. As a closed and avascular structure, an intervertebral disc consists of 2 interlinked but distinct regions, the inner nucleus pulposus and the outer annulus fibrosus. In a normal disc, the posterior annulus is weaker with higher stress load. ${ }^{31,32}$ Therefore, $P$. acnes cannot enter the normal disc. It is reported that stress distributions can be disturbed by aging and disc degeneration. Then, increased stress may lead to posterior annulus injury. ${ }^{31}$ Consequently, new angiogenesis after annulus disruption can directly influence $P$. acnes in the disc tissue. ${ }^{29}$ Thus, avascular disc tissue can provide a suitable environment for $P$. acnes proliferation, leading to a slowdeveloping infection. ${ }^{6}$ Because there is no agreement on the sources of $P$. acnes infection in patients with lumbar disc herniation, this study aimed to evaluate the bacterial infection, especially $P$. acnes, in the disc materials from patients with disc herniation.

\section{MATERIALS AND METHODS}

\section{Study Participants}

From September 2014 to July 2015, a total of 120 patients (referred to Imam Reza Hospital, Tabriz, Iran) aged 18 to 65 years old undergoing discectomy with disc herniation surgery were enrolled into the study. Inclusion criteria were defined as patients with diagnosed lumbar disc herniation at the single level of L4-L5 or L5-S1 confirmed by MRI. In this study, all patients suffering from LBP for 2 to 6 months and not responding to conservative treatment were enrolled. In addition, patients with a history of diabetes, antibiotic treatment (1 month before the surgery date), back surgery, and/or previous epidural steroid injection were excluded.

\section{Biopsy Collection}

The operation was performed via posterior approach microdiscectomy by a single senior surgeon with the patient in a prone position. In this study, infection evaluation was performed according to the method of the Infectious Diseases Society of America for investigation of prosthetic joint infection. ${ }^{33}$ In this way, 5 separate samples from disc material were surgically removed from each patient during the disc removal. Before surgery, all patients were told to take a bath. To avoid any potential contamination of excised biopsies, stringent antiseptic sterile protocols were followed and the skin of the operation field was cleaned with Betadine (a surgical scrub containing $7.5 \%$ povidone-iodine) preoperatively for $3 \mathrm{~min}$ utes, then was allowed to dry. For each individual biopsy, the disc fragment was extracted with a set of sterile instruments. One high dose of cefuroxime $(1.5 \mathrm{~g})$ was administered intravenously after the tissue samples were retrieved to prevent growth of any bacteria present in the biopsy samples. Biopsies were placed in separate sterile glass vials and immediately frozen at $-80^{\circ} \mathrm{C}$. The frozen samples were transported to Tabriz University of Medical Sciences in thermal transport boxes designed for organ transport.

\section{Bacterial Culture}

All disc samples were cut into smaller fragments, and the tissue was broken apart and ground up, using an individually packaged sterile scalpel. As a further precaution, all scalpels were dipped in $70 \%$ (vol/vol) ethanol and passed through a Bunsen burner flame before use. With a sterilized scalpel, the processed and ground-up tissue sample was first spread across the surface of a Columbia blood agar plate (Oxoid, Basingstoke, UK), and then collectively embedded into the center of the plate. ${ }^{6}$ Two sections were prepared from each individual tissue sample and one section of the tissue was incubated in an aerobic and the other in an anaerobic glove box for 7 days at $37^{\circ} \mathrm{C}(80 \%$ dinitrogen, $10 \%$ carbon dioxide, and 10\% dihydrogen).

\section{Molecular and Phenotypic Identification}

Following anaerobic and aerobic culture incubations, resulting colonies were subcultured onto Columbia blood agar plates and then incubated at $37^{\circ} \mathrm{C}$ for 24 hours in anaerobic conditions. Gram staining was performed for investigation of all colonies. For identification of presumptive $P$. acnes, a rapid ID 32A kit (bioMerieux) was used.

The cultured $P$. acnes was examined by $16 \mathrm{~S}$ rRNA (ribosomal RNA)-based polymerase chain reaction $(\mathrm{PCR})$. In this way, specific primers were designed for amplification of $P$. acnes $16 \mathrm{~S}$ rRNA. The forward primer was 5'-GGTTGTAAACCGCTTTCGCCT- $3^{\prime}$, and the reverse primer was $5^{\prime}$-GGCACACCCATCTCTGAGCAC-3' ${ }^{29}$

Genomic DNA was extracted by a rapid boil extraction method. ${ }^{34}$ The PCR was performed in a $25-\mu \mathrm{L}$ volume containing $2 \mu \mathrm{L}$ of template DNA, $19.8 \mu \mathrm{L}$ of SDW, $2.5 \mu \mathrm{L}$ of $10 \times$ PCR buffer $(10 \mathrm{mM}$ 
Table 1. Distribution of Propionibacterium acnes-infected samples according to age groups. ${ }^{a}$

\begin{tabular}{lccc}
\hline & \multicolumn{2}{c}{$P$ P. acnes } & \\
\cline { 2 - 3 } Age Groups, $\mathbf{y}$ & Positive & Negative & Total \\
\hline $18-29$ & 6 & 13 & 19 \\
$30-39$ & 16 & 19 & 35 \\
$40-49$ & 8 & 19 & 27 \\
$50-59$ & 11 & 12 & 23 \\
$60-65$ & 5 & 11 & 16 \\
Total & 46 & 74 & 120 \\
\hline
\end{tabular}

${ }^{\mathrm{a}}$ Numbers show the frequency of positive and negative samples in each group.

Tris $\mathrm{HCl} \mathrm{pH} 8.3,25 \mathrm{mM}$ potassium chloride, 3.5 $\mathrm{mM}$ magnesium chloride), $0.2 \mu \mathrm{L}$ of dNTPs $(10 \mathrm{mM}$ each nucleotide), $0.2 \mu \mathrm{L}$ of each primer $(25 \mathrm{pmol} /$ $\mu \mathrm{L}$ ), and $0.1 \mu \mathrm{L}$ of TaqDNA polymerase (1.25 units/ $\mu \mathrm{L}$ ). A negative control (sterile water as template) and a positive control (with recently amplifiable $P$. acnes DNA) were undertaken. The PCR was performed in the following conditions: initial $94^{\circ}$ $\mathrm{C}$ for denaturation (4 minutes); 35 cycles at $94^{\circ} \mathrm{C}$ for denaturation (30 seconds), $54^{\circ} \mathrm{C}$ for annealing (30 minutes), and $72^{\circ} \mathrm{C}$ for extension (1 minute); $72^{\circ}$, extension ( 4 minutes); $4^{\circ} \mathrm{C}$, hold. Amplified fragments were separated using a $2 \%$ agarose gel containing $1 \mu \mathrm{g} / \mathrm{mL}$ of ethidium bromide. Consequently, electrophoresis was performed in following condition including $0.1 \%$ (vol/vol) glacial acetic acid buffer at $100 \mathrm{~V}$ and $1 \times$ TAE (40 mM Tris, 1 mM EDTA).

\section{Minimum Inhibitory Concentration Determination by Agar Dilution}

In this study, the minimum inhibitory concentration (MIC) was determined that each isolate against different antibiotics using the Clinical and Laboratory Standards Institute reference agar dilution procedure. $^{35}$ The following antibiotics were used: gentamicin, vancomycin, rifampicin, fusidic acid, ciprofloxacin, amoxicillin, erythromycin, tetracycline, and trimethoprim (Mast Diagnostics, UK).

$P$. acnes type strain NCTC 737 (type IA1) was used as a control. Plates were incubated in an anaerobic condition at $37^{\circ} \mathrm{C}$ for 72 hours. Then, the MIC was recorded for each antibiotic at the lowest concentration in which there was no visible growth.

\section{Statistical Analysis}

Descriptive statistics (mean, standard deviation, frequency, and frequency percentage distribution) were used to describe the basic features of the data. The mean values were compared using a $t$ test and
Table 2. MIC values (mg/L) for all Propionibacterium acnes isolates recovered from discectomy tissue $(\mathrm{N}=221){ }^{a}$

\begin{tabular}{|c|c|c|c|c|c|c|c|c|}
\hline MIC (mg/L) & $\leq \mathbf{0 . 0 3}$ & 0.06 & 0.12 & 0.25 & 0.5 & 1 & 2 & $\geq 4$ \\
\hline Gentamicin & & & & & & & & 221 \\
\hline Vancomycin & & 5 & & & 81 & 135 & & \\
\hline Rifampicin & 221 & & & & & & & \\
\hline Fusidic acid & & & & & & 31 & 190 & \\
\hline Ciprofloxacin & & & & & & 221 & & \\
\hline Amoxicillin & & 91 & 130 & & & & & \\
\hline Erythromycin & 25 & 196 & & & 221 & & & \\
\hline Tetracycline & & & & & & 134 & & \\
\hline Trimethoprim & & & & & & & 35 & 186 \\
\hline
\end{tabular}

then exact chi-square test was used for comparing the categorical variables. A $P$ value $\leq .05$ was considered to be statistically significant.

\section{RESULTS}

In the present study, 120 participants with a mean age of $43.15 \pm 12.62$ years (range, 18 to 65 years) were investigated. Of those, $69(57.5 \%)$ were men and $51(42.5 \%)$ were women. The mean age of men was $41.66 \pm 12.33$ years and of women, $45.15 \pm$ 12.86 years. There was no significant difference in the age of groups $(P=.135)$. In this study, disc herniation was at the level of L4-L5 in 63 people $(52.5 \%)$ and at L5-S1 in 57 people $(47.5 \%)$. The PCR technique was used for examination of $16 \mathrm{~S}$ rDNA specific for $P$. acnes in the disc cultures. According to the results, the $16 \mathrm{~S}$ rDNA gene was identified in $46(38.3 \%)$ disc samples (Table 1). In addition, there was no significant difference in the distribution of $P$. acnes-positive samples according to 5 age groups $(P=.516$; Table 1$)$. The distribution of $P$. acnes infection in the sex groups was evaluated, and $28(23.3 \%)$ men and $18(15 \%)$ women were infected by $P$. acnes. It was shown that there was no significant relationship between sex and $P$. acnes infection $(P=.556)$. Antibiotic susceptibility was checked for $P$. acnes-positive samples. The lowest MIC value $(\leq 1 \mathrm{mg} / \mathrm{L})$ was identified for amoxicillin, ciprofloxacin, erythromycin, rifampicin, tetracycline, and vancomycin. A moderate MIC value $(1-2 \mathrm{mg} / \mathrm{L})$ was found for fusidic acid, and the highest MIC value $(\geq 2 \mathrm{mg} / \mathrm{L})$ was for gentamicin and trimethoprim (Table 2).

\section{DISCUSSION}

In the present study, $60(50 \%)$ samples were infected by different bacteria, of which $76.66 \%$ of 
infections were related to the anaerobic bacterium $P$. acnes. The findings of the present study confirmed those of other studies stating that the most frequent microorganism in the disc material (more than 70\%) is $P$. acnes. ${ }^{6,29,36-39} P$. acnes is an anaerobic-aerotolerant bacteria with a genome that encodes both oxidative phosphorylation components (such as NADH dehydrogenase/complex I, cytochrome $\mathrm{C}$ oxidase, cytochrome $\mathrm{C}$ reductase, and FOF1-type adenosine triphosphate synthase) and cytochrome D oxidase. ${ }^{40-42}$ Thus, this bacterium can grow in different conditions, can survive under anaerobic conditions in vitro for more than 8 months, and is also capable of tolerating exposure to oxygen for several hours. ${ }^{43}$ In addition, previous studies have shown that $P$. acnes is able to survive in human tissues with low oxygenation for a long period. ${ }^{41,43}$ A spinal disc is a low-oxygen environment due to the lack of vascularization. Therefore, this tissue is an ideal environment for growth of anaerobic bacteria such as $P$. acnes. Stirling et $\mathrm{al}^{6}$ showed that there is a relation between severe sciatica and $P$. acnes infection. Nineteen $(53 \%)$ patients with severe sciatica who had undergone microdiscectomy were positive for $P$. acnes bacterium. The researchers ${ }^{6}$ concluded that these microorganisms could infect the intervertebral disc after a minor trauma. In another study, Stirling et $\mathrm{al}^{36}$ demonstrated that $27(43 \%)$ cases were positive for infection; of these, 22 were associated with P. acnes. They showed that epidural injection was not related to a positive culture. ${ }^{36}$ Corsia et $\mathrm{al}^{37}$ evaluated the presence of bacterial infection in 30 individuals with lumbar and 30 with cervical disc herniation. In contrast, staphylococcus (36\%) was more frequent than $P$. acnes $(18 \%)$ in the lumbar disc herniation. In cervical herniation, they found $37 \%$ of the infection involved P. acnes. ${ }^{37}$ Similarly, Agarwal et $\mathrm{al}^{38}$ evaluated the intervertebral disc material from 52 patients who had undergone single-level microdiscectomy for lumbar disc herniation for bacterial infection; $19 \%$ of them had microorganism infection, of which $70 \%$ was related to $P$. acnes. ${ }^{38}$ In a similar study, Albert et $\mathrm{al}^{29}$ showed that $P$. acnes was the most frequent microorganism in the disc material from patients with a lumbar disc herniation. ${ }^{29}$ In this study, all the cases with history of diabetes, back surgery and/or previous epidural steroid injection were excluded to omit the risk factors of disc contamination. Previously, studies have demonstrated that contamination with this microorganism is associated with the pathogenesis of some disease such as implant-associated infections. ${ }^{44}$ For example, contamination with $P$. acnes was confirmed in the pathology of periprosthetic joint infection, wherein direct contamination of the implant and/or the surgical wound during the operation can lead to this condition. ${ }^{45-47}$ However, all the cases with history of diabetes, back surgery, and/or previous epidural steroid injection were excluded to omit the risk factors of disc contamination from this study. Consequently, the results of the present study showed that the source of infection is not related to previous contamination. Moreover, skin was cleaned preoperatively to prevent possible contamination of biopsy samples. In contrast, other studies were conducted to show that isolated bacteria from disc material in patients with microdiscectomy are associated with tissue contamination, previous back operation, or injection. Ben-Galim et $\mathrm{al}^{48}$ suspected that contamination was the reason that 2 of 30 patients had coagulase-negative staphylococcus in the evacuated nucleus material. They used one high-dose cefazolin preoperatively. They explained that low isolation rate of $P$. acnes was related to its sensitivity to this high-dose antibiotic. ${ }^{48}$ Furthermore, Carricajo et $\mathrm{al}^{49}$ showed that 2 of 54 of cases were positive for $P$. acnes and that muscle and ligamentum flavum from these 2 cases were also positive for this microorganism. They demonstrated that sample contamination might be the cause of positive $P$. acnes in the lumbar disc tissue cultures. ${ }^{49}$ In another study, Zhou et $\mathrm{al}^{50}$ showed that 11 discs and 3 muscle samples were positive for $P$. acnes. As a result, it has been confirmed that $P$. acnes growth in the muscle is related to contamination. ${ }^{50}$ In this study, tissues were cultured. Using culture is a usual technique for identification of bacteria. Our samples were incubated for 7 days. As a slow-growing anaerobic bacterium, $P$. acnes needs a prolonged incubation period in anaerobic condition. ${ }^{27,51}$ The PCR technique has been used for detection of 16S rDNA gene that is specific for $P$. acnes. $^{52}$ This technique is sensitive, effective, and quick for identifying $P$. acnes as compared with culturing methods. ${ }^{52,53}$ In this study, PCR was used for identifying bacterial infection in the cultured samples and then was specifically used for identifying $P$. acnes. Considering its advantages, PCR was also used for identifying the $P$. acnes infection in similar studies. ${ }^{50,54}$ Antimicrobial susceptibility was determined for 
cultured $P$. acnes from lumbar herniation, and the findings can provide further information for treatment regimens. In this study, low MIC values were detected for amoxicillin, ciprofloxacin, erythromycin, rifampicin, tetracycline, and vancomycin. Currently, antibiotics such as penicillin/amoxicillin, vancomycin, clindamycin, or rifampicin/linezolid are suggested for the treatment of postoperative or prosthetic infection. ${ }^{55-58}$ Albert et $\mathrm{al}^{30}$ examined the effects of antibiotics (amoxicillin/clavulanic acid) in patients with chronic LBP and type 1 Modic changes. The authors explained that this antibiotic regimen was responsible for the changes in the MRI studies as well as the observed improvement. They suggested that their regimen could act on the lowgrade $P$. acnes infection causing the low back pain as well as type 1 Modic changes in the adjacent vertebral endplates. ${ }^{30}$ In a recent study by Aghazadeh et $a{ }^{59}$ it was demonstrated that there is a positive relation between $P$. acnes and Modic changes and presence of $P$. acnes. ${ }^{59,60}$ According to the results, it can be concluded that presence of $P$. acnes in the herniated disc tissue has a suspected relationship with clinical manifestations (such as inflammation, Modic changes, and LBP). The lowest MIC value was identified for amoxicillin, ciprofloxacin, erythromycin, rifampicin, tetracycline, and vancomycin. A moderate MIC value was found for fusidic acid; the highest MIC value was for gentamicin and trimethoprim.

\section{REFERENCES}

1. Freynhagen R, Baron R, Gockel U, Tölle TR. Pain DETECT: a new screening questionnaire to identify neuropathic components in patients with back pain. Curr Med Res Opin. 2006;22(10):1911-1920.

2. Kaki AM, El-Yaski AZ, Youseif E. Identifying neuropathic pain among patients with chronic low-back pain: use of the Leeds Assessment of Neuropathic Symptoms and Signs pain scale. Reg Anesth Pain Med. 2005;30(5):422-428.

3. Sardar K, Das G, Mahta P, Mallick S, Hubbard R. Medical ozone in herniated disc: a classical review. $J$ Pain Relief. 2014;3(3):148.

4. Bogduk N, Aprill C, Derby R. Lumbar discogenic pain: state-of-the-art review. Pain Med. 2013;14(6):813-836.

5. Crock H. A reappraisal of intervertebral disc lesions. Med J Aust. 1970;1(20):983-989.

6. Stirling A, Worthington T, Rafiq M, Lambert PA, Elliott TS. Association between sciatica and Propionibacterium acnes. Lancet. 2001;357(9273):2024-2025.

7. Harris AE, Hennicke C, Byers K, Welch WC. Postoperative discitis due to Propionibacterium acnes: a case report and review of the literature. Surg Neurol. 2005;63(6):538-541.

8. Arnell K, Cesarini K, Lagerqvist-Widh A, Wester T,
Sjölin J. Cerebrospinal fluid shunt infections in children over a 13-year period: anaerobic cultures and comparison of clinical signs of infection with Propionibacterium acnes and with other bacteria. J Neurosurg Pediatr. 2008;1(5):366-372.

9. Douglas H, Gunter SE. The taxonomic position of Corynebacterium acnes. J Bacteriol. 1946;52(1):15-23.

10. Dessinioti C, Katsambas AD. The role of Propionibacterium acnes in acne pathogenesis: facts and controversies. Clin Dermatol. 2010;28(1):2-7.

11. Kirschbaum J, Kligman A. The pathogenic role of Corynebacterium acnes in acne vulgaris. Arch Dermatol. 1963;88(6):832-833.

12. Billis A. Propionibacterium acnes associated with inflammation in radical prostatectomy specimens: a possible link to cancer evolution? J Urol. 2005;31(5):500-502.

13. Schupp JC, Tchaptchet S, Lützen $\mathrm{N}$, et al. Immune response to Propionibacterium acnes in patients with sarcoidosis - in vivo and in vitro. BMC Pulm Med. 2015;15(1):75.

14. Eishi Y, Suga M, Ishige I, et al. Quantitative analysis of mycobacterial and propionibacterial DNA in lymph nodes of Japanese and European patients with sarcoidosis. J Clin Microbiol. 2002;40(1):198-204.

15. Colina M, Monaco AL, Khodeir M, Trotta F. Propionibacterium acnes and SAPHO syndrome: a case report and literature. Clin Exp Rheumatol. 2007;25:457-460.

16. Conen A, Walti LN, Merlo A, Fluckiger U, Battegay M, Trampuz A. Characteristics and treatment outcome of cerebrospinal fluid shunt-associated infections in adults: a retrospective analysis over an 11-year period. Clin Infect Dis. 2008;47(1):73-82.

17. Thompson T, Albright AL. Propionibacterium acnes infections of cerebrospinal fluid shunts. Childs Nerv Syst. 1998;14(8):378-380.

18. Deramo VA, Ting TD. Treatment of Propionibacterium acnes endophthalmitis. Curr Opin Ophthalmol. 2001;12(3):225229.

19. Seng P, Bayle S, Alliez A, Romain F, Casanova D, Stein A. The microbial epidemiology of breast implant infections in a regional referral centre for plastic and reconstructive surgery in the south of France. Int J Infect Dis. 2015;35(June):62-66.

20. Del Pozo JL, Tran NV, Petty PM, et al. Pilot study of association of bacteria on breast implants with capsular contracture. J Clin Microbiol. 2009;47(5):1333-1337.

21. Delahaye F, Fol S, Celard M, et al. Propionibacterium acnes infective endocarditis. Study of 11 cases and review of literature [in French]. Arch Mal Coeur Vaiss. 2005;98(12):12121218 .

22. Schroeder JE, Girardi FP, Sandhu H, Weinstein J, Cammisa FP, Sama A. The use of local vancomycin powder in degenerative spine surgery. Eur Spine J. 2016;25(4):1029-1033.

23. Lall RR, Wong AP, Lall RR, Lawton CD, Smith ZA, Dahdaleh NS. Evidence-based management of deep wound infection after spinal instrumentation. J Clin Neurosci. 2015;22(2):238-242.

24. Haidar R, Najjar M, Boghossian AD, Tabbarah Z. Propionibacterium acnes causing delayed postoperative spine infection: review. Scand J Infect Dis. 2010;42(6-7):405-411.

25. Trampuz A, Widmer AF. Infections associated with orthopedic implants. Curr Opin Infect Dis. 2006;19(4):349-356.

26. Klatte TO, Sabihi R, Guenther D, et al. High rates of occult infection after shoulder fracture fixation: considerations 
for conversion shoulder arthroplasty. HSS J. 2015;11(3):198203.

27. Zeller V, Ghorbani A, Strady C, Leonard P, Mamoudy P, Desplaces N. Propionibacterium acnes: an agent of prosthetic joint infection and colonization. J Infect. 2007;55(2):119-124.

28. Butler-Wu SM, Burns EM, Pottinger PS, et al. Optimization of periprosthetic culture for diagnosis of Propionibacterium acnes prosthetic joint infection. J Clin Microbiol. 2011;49(7):2490-2495.

29. Albert HB, Lambert P, Rollason J, et al. Does nuclear tissue infected with bacteria following disc herniations lead to Modic changes in the adjacent vertebrae? Eur Spine $J$. 2013;22(4):690-696.

30. Albert HB, Sorensen JS, Christensen BS, Manniche C. Antibiotic treatment in patients with chronic low back pain and vertebral bone edema (Modic type 1 changes): a double-blind randomized clinical controlled trial of efficacy. Eur Spine J. 2013;22(4):697-707.

31. Adams M, McNally D, Dolan P. Stress distributions inside intervertebral discs. The effects of age and degeneration. J Bone Joint Surg. 1996;78(6):965-972.

32. Tsuji H, Hirano N, Ohshima $H$, Ishihara $H$, Terahata N, Motoe T. Structural variation of the anterior and posterior anulus fibrosus in the development of human lumbar intervertebral disc. A risk factor for intervertebral disc rupture. Spine (Phila Pa 1976). 1993;18(2):204-210.

33. Osmon DR, Berbari EF, Berendt AR, et al. Diagnosis and management of prosthetic joint infection: clinical practice guidelines by the Infectious Diseases Society of America. Clin Infect Dis. 2012;56(1):1-10.

34. Caddick JM, Hilton AC, Rollason J, Lambert PA, Worthington T, Elliott TS. Molecular analysis of methicillinresistant Staphylococcus aureus reveals an absence of plasmid DNA in multidrug-resistant isolates. FEMS Immunol Med Microbiol. 2005;44(3):297-302.

35. Clinical and Laboratory Standards Institute (CLSI). Methods for Dilution Antimicrobial Susceptibility Tests for Bacteria That Grow Aerobically. Approved Standard M7-A7. Wayne, PA: CLSI; 2006.

36. Stirling A, Rafiq M, Mathur K, Elliott T, Worthington $\mathrm{T}$, Lambert P. Association between sciatica and skin commensals. J Bone Joint Surg. 2002;84(suppl 2):147.

37. Corsia M, Wack M, Denys G, eds. Low vitulence bacterial infections of intervertebral discs and the resultant spinal disease processes [abstract]. Scoliosis Research Society Annual Meeting; 2003.

38. Agarwal V, Golish SR, Alamin TF. Bacteriologic culture of excised intervertebral disc from immunocompetent patients undergoing single level primary lumbar microdiscectomy. $J$ Spinal Disord Tech. 2011;24(6):397-400.

39. Fritzell P, Bergström T, Welinder-Olsson C. Detection of bacterial DNA in painful degenerated spinal discs in patients without signs of clinical infection. Eur Spine J. 2004;13(8):702706.

40. Brüggemann H. Insights in the pathogenic potential of Propionibacterium acnes from its complete genome. Semin Cutan Med Surg. 200524(2):67-72.

41. Cove J, Holland K, Cunliffe W. Effects of oxygen concentration on biomass production, maximum specific growth rate and extracellular enzyme production by three species of cutaneous propionibacteria grown in continuous culture. J Gen Microbiol. 1983;129(11):3327-3334.

42. Gribbon EM, Shoesmith J, Cunliffe W, Holland K. The microaerophily and photosensitivity of Propionibacterium acnes. J Appl Bacteriol. 1994;77(5):583-590.

43. Csukás Z, Banizs B, Rozgonyi F. Studies on the cytotoxic effects of Propionibacterium acnes strains isolated from cornea. Microb Pathog. 2004;36(3):171-174.

44. Portillo ME, Corvec S, Borens O, Trampuz A. Propionibacterium acnes: an underestimated pathogen in implant-associated infections. BioMed Res Int. 2013;2013.

45. Trampuz A, Piper KE, Jacobson MJ, et al. Sonication of removed hip and knee prostheses for diagnosis of infection. New Engl J Med. 2007;357(7):654-663.

46. Cobo J, Del Pozo JL. Prosthetic joint infection: diagnosis and management. Expert Rev Anti Infect Ther. 2011;9(9):787802.

47. Zimmerli W, Trampuz A, Ochsner PE. Prosthetic-joint infections. New Engl J Med. 2004;351(16):1645-1654.

48. Ben-Galim P, Rand N, Giladi M, et al. Association between sciatica and microbial infection: true infection or culture contamination? Spine (Phila Pa 1976). 2006;31(21):2507-2509.

49. Carricajo A, Nuti C, Aubert E, et al. Propionibacterium acnes contamination in lumbar disc surgery. J Hosp Infect. 2007;66(3):275-277.

50. Zhou Z, Chen Z, Zheng Y, et al. Relationship between annular tear and presence of Propionibacterium acnes in lumbar intervertebral disc. Eur Spine J. 2015;24(11):2496-2502.

51. de Morais Cavalcanti SM, de França ER, Lins AK, Magalhães M, de Alencar ERB, Magalhães V. Investigation of Propionibacterium acnes in progressive macular hypomelanosis using real-time $\mathrm{PCR}$ and culture. Int $J$ Dermatol. 2011;50(11):1347-1352.

52. Nakamura M, Kametani I, Higaki S, Yamagishi T. Identification of Propionibacterium acnes by polymerase chain reaction for amplification of $16 \mathrm{~S}$ ribosomal RNA and lipase genes. Anaerobe. 2003;9(1):5-10.

53. Yang S, Rothman RE. PCR-based diagnostics for infectious diseases: uses, limitations, and future applications in acute-care settings. Lancet Infect Dis. 2004;4(6):337-348.

54. Rollason J, McDowell A, Albert HB, et al. Genotypic and antimicrobial characterisation of Propionibacterium acnes isolates from surgically excised lumbar disc herniations. BioMed Res Int. 2013;2013.

55. Jakab E, Zbinden R, Gubler J, Ruef C, Von Graevenitz A, Krause M. Severe infections caused by Propionibacterium acnes: an underestimated pathogen in late postoperative infections. Yale J Biol Med. 1996;69(6):477-482.

56. Bayston R, Nuradeen B, Ashraf W, Freeman BJ. Antibiotics for the eradication of Propionibacterium acnes biofilms in surgical infection. $J$ Antimicrob Chemother. 2007;60(6):1298-1301.

57. Nisbet M, Briggs S, Ellis-Pegler R, Thomas M, Holland D. Propionibacterium acnes: an under-appreciated cause of post-neurosurgical infection. $J$ Antimicrob Chemother. 2007;60(5):1097-1103.

58. Levy PY, Fenollar F, Stein A, et al. Propionibacterium acnes postoperative shoulder arthritis: an emerging clinical entity. Clin Infect Dis. 2008;46(12):1884-1886.

59. Aghazadeh J, Salehpour F, Ziaeii E, et al. Modic changes in the adjacent vertebrae due to disc material infection with 
Propionibacterium acnes in patients with lumbar disc herniation. Eur Spine J. 2017;26(12):3129-3134.

60. Javanshir N, Salehpour F, Aghazadeh J, Mirzaei F, Naseri Alavi SA. The distribution of infection with Propionibacterium acnes is equal in patients with cervical and lumbar disc herniation. Eur Spine J. 2017;26(12):3135-3140.

Disclosures and COI: The authors received no funding for this study and report no conflicts of interest.

Corresponding Author: Seyed Ahmad Naseri
Alavi, Department of Neurosurgery, Faculty of Medicine, Tabriz University of Medical Sciences, Tabriz, Iran. Phone: +989116137353; Email: dr. arsalan2010@gmail.com.

Published 30 April 2019

This manuscript is generously published free of charge by ISASS, the International Society for the Advancement of Spine Surgery. Copyright (C) 2019 ISASS. To see more or order reprints or permissions, see http://ijssurgery.com. 